Received: October 25, 2017

Revision received: April 2, 2018

\title{
Theoretical Basis of Minority Language Education from an International Perspective
}

\author{
Yandan Zhang ${ }^{1}$ \\ Guanghua Law School Zhejiang University; \\ Law School Guizhou University
}

\begin{abstract}
Minority language education is an important and non-exclusive way to promote the inheritance of national language and culture, in various sovereign countries, its realization degree and obtained effect are different. Based on affirmation of the value of national language education, this paper analyzes three kinds of theoretical basis of national language education in international documents, namely the emphasis of culture, the realization of linguistic diversity and the wide adoption of human rights discourse, so as to urge sovereign countries to take their international obligation of national language education seriously and fulfil it, and to promote the renewal and development of national language education in the new era.
\end{abstract}

\section{Keywords}

Minority Language Education • Cultural Connection • Cultural Diversity • Human Rights

\footnotetext{
${ }^{1}$ Correspondence to: Guanghua Law School, Zhejiang University, Hangzhou 310008 China; Law School, Guizhou University, Guiyang 550025 China; Email: klzyd555@ sohu.com.
} 
In any multinational country, minority language education is not only a question of intergenerational transmission of national language and culture, but also an important factor affecting national unity and stability of the country. From a global perspective, minority language education generally presents a trend of negative decline. In particular, the strong invasion of international language brought about by globalization has made the promotion of minority language education more difficult. In order to urge the sovereign countries to pay attention to and work hard to implement the obligation of national language education, and to promote the renewal and development of the national language education in the new era, the international community has formulated international obligations on the promotion of national language education to varying degrees in international documents developed by the international community at different times. Objectively speaking, the provisions on minority language education in international documents are very similar in content, but the underlying basic principles are often different, indicating that there are differences of each national organization in their focus and direction on national language education emphasis. How can international regulations related to national language education be properly guaranteed and realized under different theoretical guidance, for existing international documents, there are considerations from three aspects: (MoriaPaz, 2013)

\section{Emphasis on cultural connection}

Sociolinguists are accustomed to attribute the attitudes of people in society to language as two dimensions to understand a language, that is, the dimension of communication and the dimension of culture. The communication dimension of language is a direct reflection of the understanding of the instrumental value of language in early stage. This dimension does not pay attention to the intrinsic value of language. It only regards language as a tool of communication or the realization of other rights (right to education and freedom of speech), so as to ensure that language does not prevent people from fully enjoying certain rights with linguistic characteristics, does not hinder people from participating in public institutions or democratic processes, and does not prevent people from entering social or economic societies that require language skills. Compared with the communication dimension, the cultural dimension of language emphasizes the intrinsic value of language as a cultural heritage and a status symbol. This value focuses more on the inner relationship between language and culture. Objectively speaking, any language has the dual functions of communication and cultural value. The two usually condition each other and interact as both cause and effect. The reason why a language exhibits a single-function visual effect is simply because the language exhibits different states in different stages of social development to adapt to different needs.

Among all linguistic forms, minority language is the most appropriate form of language that reflects the intrinsic link between language and culture. As a core element of national culture, minority language not only serves as a way of functional communication, but more importantly, it records the evolution of history and the progress of civilization. It is a symbol of the continuation of national history and cultural independence, and its existence constitutes an important source of national identity and cultural identity. (Adams, 2006) In the 19th century, when emphasizing the role of language for a nation and relationship between language and national spirit, the distinguished German anthropologist William von Humboldt had pointed out that: language is the breath of a nation's existence and the soul of a nation. "The combination of the spiritual characteristics and 
language formation of a nation is extremely close, as long as one aspect exists, the other aspect must be fully derived from it. The spirit of a nation is the language of the nation." When a national language is lost, linguist Ken Hale emphasizes: "Then you lose a culture, a wealth of knowledge and a work of art. It's like casting a bomb at the Louvre Museum." As for the close relationship between national language and national culture, in order to continue the national culture, the survival and development of the national language has become the key. In all forms that achieving continuing of national culture and national spirit by national language, school education of national language is one of them, but practice has proved that it is indeed the most direct and most effective way (Donna, 1994). It not only provides the most formalized, scientific, and systematic teaching model for the study of national languages, but more importantly, it conveys the positive energy of the state to support the study of national languages, and it provides a non-unique but extremely important means for the development and use of national language resources. In the long-term practice, the World Bank has also confirmed that children who are educated in their native language are more productive and more successful than those who simply taught in the official language (see Figure 1).

In Mali, children who are taught in their own language (black) are $32 \%$ more likely to pass the exam than those who taught only in the official language French (gray).

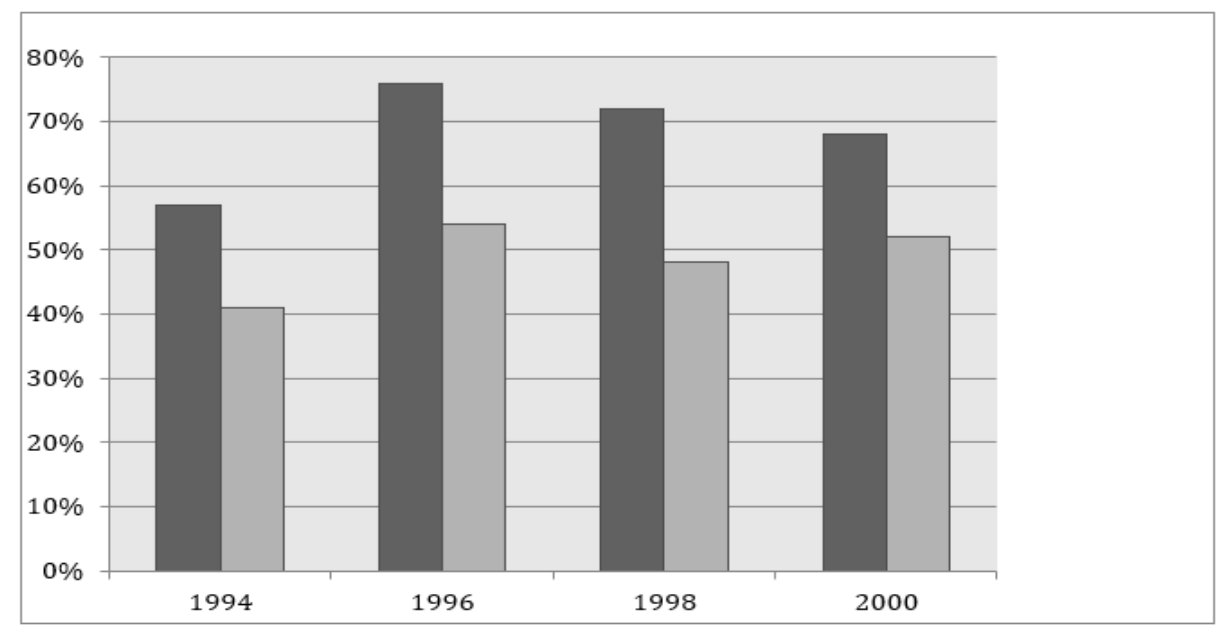

Figure 1. Primary school graduation test passing rate, 1994-2000

Source: World Bank, In Their Own Language: Education for All (In their own language: education for all) (World Bank: Washington, 2005).

International documents that use cultural dimension to focus on national language education are widely found in the international community, such as the 1960 Convention against Discrimination in Education, especially the 1992 European Charter for Regional or Minority Languages, in its preface, it clearly expresses that national language is the most basic component of national identity, conveys the core concept that respecting one's dignity, respecting people's identity and respecting people's language are closely related, moreover, in the $8^{\text {th }}$ clause of the convention, it specifies that, at the request of a sufficient number of students or parents, minority 
languages should be used as teaching language in preschool, primary school, middle \& high school, university and continuing education stages.

\section{The purpose of achieving cultural diversity as a whole}

Another theoretical basis for minority language education proposition benefits from the development of the ecological world outlook. Ecological world outlook is an idea which pursues ecological balance and harmonious development, and it is initiated under the ecological crisis. Faced with the fact that a large number of national languages in the world are rapidly decreasing and disappearing, language ecologists firmly believe that linguistic diversity and biodiversity have similar functions. The reduction and disappearance of languages is like the reduction and disappearance of species in the biological world, it is a prelude to a large language ecological crisis and disaster. According to the internationally accepted indicators and methods for studying species extinction, the speed of human language demise is higher than the extinction rate of species (see Figure 2) (Sutherland, 2003). In view of this, in order to arouse greater concern for language problems in human society, language ecologists have even borrowed a large number of ecological terms such as "endangered extinction" and "death" to describe the overall status of national languages and speculate on their future destiny. These scholars believe that biodiversity is beneficial to maintaining the balance and stability of the entire ecosystem. Thus, the same can be said that national language, as the basic element of national culture, contains a large number of human cognition and cultural achievements about the natural world. The preservation of its diversity will enrich and prosper cultural diversity and the diversity of the world. To illustrate the importance of linguistic diversity in maintaining the linguistic ecological environment, British scholar Colin Baker even cited the "Language Ecology model" (Ramanjaney, 2017) proposed by Ofelia Garcia to demonstrate it. The Language Ecology model points out that just as the diversity of flowers' variety, color, shape and size can give viewers visual pleasure and aesthetic pleasure, diverse and rich language types are also extremely important to eliminate the monotony of the existing world. Of course, in order to maintain the existence of this diversity, language must be carefully maintained and cared for as a garden, because once the diversity of languages is lost, the human culture and spiritual world based on it will vanish, it will eventually lead to the loss of cultural diversity and the diversity of the world, (Blommaert, Review and Skutnabb, 2001) and this will cause disastrous consequences and irreparable losses for the sustainable development of human civilization.

Figure 2

Comparisons of the Threats to Birds and Languages in Relation to Population Size and Decline

\begin{tabular}{lccc}
\hline Category & Extinct & Critical & Endangered \\
\hline Languages & $306(4.5 \%)$ & $438(7.1 \%)$ & $506(8.2 \%)$ \\
Birds & $125(1.3 \%)$ & $182(1.9 \%)$ & $321(3.3 \%)$ \\
Mammals & $87(1.9 \%)$ & $180(4.1 \%)$ & $340(7.7 \%)$ \\
\hline
\end{tabular}

Taking biodiversity to allude to cultural diversity as a counterattack against national language assimilation and national language discrimination is the reason why minority language education proposition is stronger, and it provides equal status and tolerant space for language education of different nationalities. The setting of this kind of theory is especially helpful to solve the problem of unfair distribution of national language education resources caused by the single-dimensionality of language learning under the development of globalization, that 
is, due to the rapid development of strong languages such as English under globalization, the more advantageous resources in language education, such as class time setting and learning time allocation are turned to foreign language learning, which not only affects the enthusiasm of national students to learn national language and national culture, but also seriously sabotages the intergenerational communication and inheritance of national language, and it's detrimental to the maintenance of national linguistic diversity and the harmony of the entire language ecology.

The international community pays close attention to the value and significance of national language education in maintaining linguistic diversity and cultural diversity, and defends the importance of national language education through various legislative activities and actions. For example, the Convention on the Rights of the Child adopted by the UN General Assembly in 1989, the Language and Education Principles promulgated by UNESCO in 2003, the Hague Recommendations regarding the Education Rights of National Minorities, and the Framework Convention for the Protection of National Minorities adopted by the OSCE in 1996, have supported the basic principles of national language education to varying degrees, which guarantees equal opportunities for members of all ethnic minorities at all stages of education, (Hakuta, 2011) and obliges member states to do their utmost to formulate and implement various strategies and policies that are conducive to the diversity of national language and national language education.

\section{Widespread adoption of human rights discourse}

The development and dissemination of the doctrine of human rights was a major achievement in the field of liberal thought after the Second World War.

Human rights, as an inseparable part of the legal revolution after the Second World War, stems from the reflection of human dignity and embodies the minimum need for human to live with dignity. The current international law and national legal system are strongly influenced by the doctrine of human rights, from the formulation of the rights to the implementation, the imprints of human rights discourse are reflected everywhere. We have to admit that the legal status of many subjects in modern society can be greatly improved in the short term, to a large extent, it is inseparable from the idea of resorting to human rights. The ace of the concept of human rights has also attracted many activists of minority languages, international lawyers and scholars to try to use familiar human rights discourse as the first choice for dealing with minority language education.

Scholars who support to use human rights discourse to address minority language education proposition firmly believe that, for ethnic minorities, the right and freedom to use their mother tongue is a minimum need for them to maintain a dignified life, effectively providing public education that is taught in minority mother languages is a good reflection of national self-esteem, certainly it's also an unshakable obligation of the country in which it is located. The frequent occurrence of language-related ethnic conflicts and violence in society is because the attitudes and methods of the state's treatment of national language education have seriously affected or even deprived the people of the minimum need for a dignified life. Both facts of history and practices of reality have proved that in an inclusive society, social stability and unity can be achieved through respect for 
the rights of national language education. Of course, although the human rights value of minority language education proposition is generally accepted, scholars have expressed different views on the scope and extent of the rights enjoyed by ethnic minorities. Many scholars advocate that national language education should give absolute protection to mother-tongue education, that is, the state should meet all the requirements of developing mother tongue in education, regardless of factors such as cost and resources; other scholars believe that because each country has different abilities and resources to fulfill its national language education obligations, and each nation's needs for mother-tongue education will be different, the degree of protection will vary, but this difference is definitely not an excuse for a country to shirk the obligation of national language education. When the population size, population concentration, and common desire for demand of a minority nationality reach a certain level, the state's refusal to grant mother tongue protection in national language education will be a violation of the basic human rights of the nation.

Using human rights discourse as a commitment to address national language education proposition is reflected in major international human rights treaties and conventions. The most notable example is the provision of $27^{\text {th }}$ article of the International Covenant on Civil and Political Rights, which states that " in those States in which ethnic, religious or linguistic minorities exist, persons belonging to such minorities shall not be denied the right, in community with the other members of their group, to enjoy their own culture, to profess and practice their own religion, or to use their own language." This article is recognized by the academic community as the most expressly recognized international human rights treaty for ethnic minorities to enjoy their own language rights. Although this article does not directly address the provisions on minority language education, the right to take one's own mother language as the teaching language during education is undoubtedly the substance of minority language rights. In addition, the Declaration on the Rights of Persons Belonging to National or Ethnic, Religious and Linguistic Minorities, adopted by the UN General Assembly in 1992, is a continuation of the $27^{\text {th }}$ article of the International Covenant on Civil and Political Rights regarding the continuation and development of the protection of the rights of minority languages, the Declaration clearly states that States should take appropriate measures in the field of education, where appropriate, to give ethnic minorities ample opportunities to learn their mother tongue or to use their mother tongue in teaching, wherever possible. The biggest feature of the declaration is that it breaks through the negative expression of the existing international documents on state obligations and establishes the positive nature of the state's obligations to protect minority language education.

It is undeniable that there are often differences in the direction and focus of national language education under the guidance of different theoretical foundations, but this difference is not an excuse for sovereign states to mitigate or exempt corresponding obligations. To elaborate the different theoretical foundations of minority language education is not to evaluate the advantages and disadvantages, or to choose one to guide all national language education practices. Its most important purpose is to provide theoretical guidance for the value of national language education and urge the sovereign states to correct their attitude of national language education, and provide qualified ethnic minorities with corresponding conditions and services for national language education as much as possible. But for now, for the work in national language education, the sovereign states still have a long way to go. 


\section{References}

Adams, M. (2006). Hybridizing habitus and reflexivity: Towards an understanding of contemporary identity. Sociology 40, http://dx.doi. org/10.2307/42856868.

Blommaert, J. (2001). Review of T. Skutnabb-Kangas, linguistic genocide in education—or worldwide diversity and human rights, Applied Linguistics, 22.

MoriaPaz. (2013). The Failed Promise of Language Rights: A Critique of The International Language Rights Regime, Harvard International Law Journal.

Donna P. (1994). Minority language education and social context, Études/Inuit/Studies 18, 189. http://dx.doi. org/10.2307/42870540.

Humboldt. (2004). On the differences in human language structures and their impact on human spiritual development. Beijing: commercial press, 17.

Upadhyay R.K., \& Hasnain, S.I. (2017). Linguistic diversity and biodiversity. Lingua 195, 113. http://dx.doi. org/10.1016/j.lingua.2017.06.002.

Sutherland, W. J. (2003). Parallel extinction risk and global distribution of languages and species. Nature, 423(6937), 276. http://dx.doi. org/10.1038/nature01607.

Hakuta, K. (2011). Educating language minority students and affirming their equal rights: Research and practical perspectives. Educational Researcher, 40(4), 163-174. http://dx.doi. org/10.3102/0013189X11404943. 